\title{
EVALUATION OF ANTIMICROBIAL, CYTOTOXICITY, AND DYEING PROPERTIES OF PRODIGIOSIN PRODUCED BY SERRATIA MARCESCENS STRAIN JAR8
}

\author{
RITIKA CHAUHAN ${ }^{1}$, ANIKET CHOUDHURI ${ }^{2}$, JAYANTHI ABRAHAM ${ }^{3 *}$
}

${ }^{1}$ Department of Biotechnology , The Oxford College of Science, HSR Layout, Bengaluru, Karnataka, India. ${ }^{2}$ Department of Food Science and Agriculture Chemistry, Mcgill MacDonald Campus, Sainte Anne de Bellevue, Montreal, Canada. ${ }^{3}$ Department of Agricultural Chemistry and Environmental Science, Microbial Biotechnology Laboratory, School of Biosciences and Technology, VIT University, Vellore, Tamil Nadu, India. Email: jayanthi.abraham@gmail.com

Received: 27 February 2017, Revised and Accepted: 12 May 2017

\section{ABSTRACT}

Objective: Prodigiosin is a red tripyrrole pigment which is synthesized as a secondary metabolite by biotypes A1, A2, and A6 of Serretia marcescens. This study was aimed to optimize production parameters for prodigiosin pigment produced by S. marcescens strain JAR8 and to determine its antimicrobial, cytotoxicity, and dyeing properties.

Methods: The effect of various media components, process parameters (temperature, $\mathrm{pH}$, incubation period), and other supplements was investigated, and the maximum production of prodigiosin was found to be at temperature $28^{\circ} \mathrm{C}, \mathrm{pH} 7.0$, incubation period of 5 day with peptone in the media. Antibacterial, cytotoxicity, and dyeing properties of prodigiosin were studied in depth.

Results: The antimicrobial study of prodigiosin revealed that it is a potent inhibitor of Gram-positive bacteria as well as Gram-negative bacteria. The prodigiosin exhibited commendable dose-dependent cytotoxicity effect against human bone cancer cells with the IC50 of $108 \mu \mathrm{g} / \mathrm{ml}$. Prodigiosin produced by strain JAR8 resisted the action of acid, alkali and detergent when applied to textile cloth.

Conclusion: The deep red pigment prodigiosin produced by strain JAR8 is economically effective and can be categorized as microbial natural product for further pharmaceutical applications.

Keywords: Biopigments, Clinical pathogens, Cytotoxicity, Natural products, Osteosarcoma cells, Prodigiosin.

(c) 2017 The Authors. Published by Innovare Academic Sciences Pvt Ltd. This is an open access article under the CC BY license (http://creativecommons. org/licenses/by/4. 0/) DOI: http://dx.doi.org/10.22159/ajpcr.2017.v10i8.18173

\section{INTRODUCTION}

Microbial natural products are critical sources of potential medicinal use majorly known as secondary metabolites. There are number of microorganisms which produce pigments and represents important class of secondary metabolites. These are small molecular weight compounds often referred as "biopigments" which can be obtained from two major sources, plants and microorganisms [1]. The pigment production from microorganisms is found to be economical and feasible as it includes easy and fast growth in culture medium. When compared to plant sources [2], it has been reported that microorganisms produce a large variety of stable pigments such as carotenoids, flavonoids, quinones, and rubramines, and the microbial fermentation has higher yields in pigment production and lower residues compared to the use of plants and animals [3]. Among microbial pigments, prodigiosin belongs to the family of natural red pigment extensively characterized by pyrrolylpyrromethane skeleton possessing low molecular weight of 323.4Da which develops in the late stages of bacterial growth. There are several other bacterial species which produce bioactive compounds, such as Vibrio psychroerythrus, Pseudomonas magnesiorubra, Alteromonas rubra, Streptomyces spp., and Nocardia sp. [4]. Prodigiosin is a red pigment which is an alkaloid being first identified and characterized in Serretia marcescens and have been fully investigated $[5,6]$. The effective clinical properties of prodigiosin imply it as antibacterial, antitumor [7], immunosuppressive [8], phytopathogenic fungal inhibitor agent [9]. The major advantage of pigment production from microorganisms includes easy doubling time, specific growth rate, fast in the cheap culture medium, and optimal environmental parameter [10]. The standardization of culture medium and fermentation conditions plays a very crucial role in the maximum production of prodigiosin.
In the present investigation, isolation characterization and cytotoxicity activity of prodigiosin from $S$. marcescens strain JAR8 for pharmaceutical applications are being reported.

\section{METHODS}

\section{Sample collection}

Sewage water and soil samples were collected aseptically from different parts of VIT University, Vellore, was screened for S. marcescens. The collected soil samples were air dried and then serially diluted on nutrient agar plates and soybean casein digest agar plates. The red pigment colonies were purified after incubation at $28^{\circ} \mathrm{C}$ for $24 \mathrm{hr}$ and preserved at $4^{\circ} \mathrm{C}$.

\section{Identification and characterization}

The molecular characterization of the isolated strain was performed by 16S rRNA nucleotide gene sequencing was submitted in NCBI Genbank. The extraction of whole genomic DNA from strain JAR8 was performed by following standard protocol described by Liu etal. [11]. The amplification of 16S-rRNA gene of strain JAR8 was carried out using forward primer

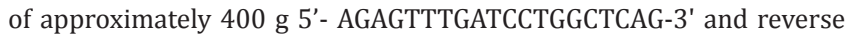
primer of $400 \mathrm{ng}$ 5'- GGTTACCTTGTTACGACTTC-3' [12]. The reaction mixture of $100 \mu$ l was prepared by mixing $2.5 \mathrm{mM}$ each of dNTPs, $10 \mathrm{X}$ Taq polymerase assay buffer, and Taq DNA polymerase enzyme. The polymerase chain reaction (PCR) amplification reaction comprises initial denaturation at $94^{\circ} \mathrm{C}$ for 5 minutes, and denaturation of the DNA was improved by adding $5 \%(\mathrm{v} / \mathrm{v})$ dimethyl sulfoxide (DMSO) to the reaction mixture. The denaturation and annealing at $55^{\circ} \mathrm{C}$ for 30 seconds was followed by final extension at $72^{\circ} \mathrm{C}$ using $\mathrm{MgCl}_{2}$ with $1.5 \mathrm{mM}$ final concentration. The obtained PCR reaction mixture was analyzed by agarose gel electrophoresis. The nucleotide sequence of the 16S rRNA gene of JAR8 strain was determined with primer using ABI 
3730xl genetic analyzer (Amnion Biosciences Pvt. Ltd.). The homology search was performed using BLAST search algorithm. The nucleotide sequence of the whole gene 16S rRNA gene has been submitted in the Gen Bank (EMBL) under accession number KF709428.

\section{Optimization and mass production}

The production of prodigiosin was determined in nutrient broth, peptone glycerol broth, Luria-Bertani broth, and soybean casein digest broth. The medium showing maximum production of pigment was used for the growth of $S$. marcescens [13]. $250 \mathrm{ml}$ of nutrient broth in Erlenmeyer flask was inoculated with $5 \%$ of $S$. marcescens JAR8 and was incubated on rotary shaker at $120 \mathrm{rpm}$ for $48 \mathrm{hr}$. After the incubation was completed, the seed medium was inoculated into $2.5 \mathrm{~L}$ of peptone glycerol medium in the fermentor for 5 days which was constantly monitored by optimum temperature and $\mathrm{pH}$. The fermentation was carried out for 5 days, and the pigment was allowed to settle down overnight in the fermentor. The settled mass was then carefully extracted from the fermentor and allowed to dry for 2 days. The obtained culture medium was centrifuged at $4000 \mathrm{rpm}$ for 30 minutes and supernatant was discarded after centrifugation. $5 \mathrm{ml}$ of ethyl acetate, ethanol and methanol was added subsequently to the pellet and again centrifuged at $2000 \mathrm{rpm}$ for 30 minutes. The supernatant was collected and stored in small vials at $4^{\circ} \mathrm{C}$ for further analysis [13].

\section{Thin layer chromatography}

The methanol extract of prodigiosin was separated on preparative silica-coated plates by solvent system containing methanol, ethyl acetate and chloroform in the ratio of $6: 3: 1(\mathrm{v} / \mathrm{v}) .10 \mu \mathrm{L}$ of methanolic extract of prodigiosin was loaded onto the silica gel slides and run against the solvent till the solvent front reached $2 / 3^{\text {rd }}$ of the slide. After the development of the chromatograms, slides were removed and dried. The rate of flow (Rf) values of the chromatogram was calculated [14].

\section{Antimicrobial activity}

The antimicrobial activity of prodigiosin from $S$. marcescens was determined against various clinical isolates such as Staphylococcus aureus NCIM 5021, Escherichia coli NCIM 2645, Pseudomonas aeruginosa NCIM 5029, Klebsiella pneumoniae NCIM 2957, Shigella sp., Salmonella sp., Proteus mirabilis, Alcaligenes sp., and Bacillus subtilis. The bacterial pathogens NCIM 5021, NCIM 2645, NCIM 5029, NCIM 2957 were procured from National collection of industrial microorganisms, Pune, India, and clinical pathogens Shigella sp., Salmonella sp., P. mirabilis, Alcaligenes sp., and B. subtilis were procured from Microbial Biotechnology Laboratory, SBST, VIT University, Vellore, Tamil Nadu, India. The bacterial pathogens were swabbed onto MuellerHinton agar plates, and a sterile cork borer was used to punch four wells onto the plates. The powdered prodigiosin pigment extracted from different solvents was mixed in sterile distilled water, and $100 \mu \mathrm{g} / \mathrm{ml}$ of the extract was used to evaluate antimicrobial activity. To the wells, different concentration $(25 \mu \mathrm{l}, 50 \mu \mathrm{l}, 75 \mu \mathrm{l}$ and $100 \mu \mathrm{l})$ of prodigiosin was added and the plates were then incubated at $37^{\circ} \mathrm{C}$ for $24 \mathrm{hr}$. The zone of inhibition around each well was measured and recorded as antimicrobial effect [15].

\section{Cytotoxicity effects}

The human bone cancer cell line (MG 63) was obtained from National Centre for Cell Science, Pune, and grown in eagle's minimum essential medium containing $10 \%$ fetal bovine serum (FBS). All cells were maintained at $37^{\circ} \mathrm{C}, 5 \% \mathrm{CO}_{2}, 95 \%$ air, and $100 \%$ relative humidity. The monolayer cells were detached with trypsin-ethylenediaminetetraacetic acid to make single cell suspensions, and viable cells were counted using a hemocytometer and diluted with medium containing 5\% FBS to give final density of $1 \times 10^{5}$ cells $/ \mathrm{ml} .100 \mu \mathrm{l}$ per well of cell suspension were seeded into 96-well plates at plating density of 10,000 cells/well and incubated to allow for cell attachment at $37^{\circ} \mathrm{C}, 5 \% \mathrm{CO}_{2}, 95 \%$ air, and $100 \%$ relative humidity [16].

After $48 \mathrm{hr}$ of incubation, $15 \mu \mathrm{l}$ of MTT $(5 \mathrm{mg} / \mathrm{ml})$ in phosphate buffered saline was added to each well and incubated at $37^{\circ} \mathrm{C}$ for $4 \mathrm{hr}$. The medium with MTT was separated, and the formazan formed crystals were solubilized in $100 \mu \mathrm{l}$ of DMSO and then measured the absorbance at $570 \mathrm{~nm}$ using microplate reader. The percentage cell inhibition was determined using the following formula: $\%$ cell inhibition $=100-\mathrm{Abs}$ (sample)/Abs (control) $\times 100[17,18]$. Nonlinear regression graph was plotted between \% cell inhibition and log concentration and IC50 was determined using GraphPad Prism software.

\section{Dyeing properties}

The dyeing ability of prodigiosin pigment was analyzed using $1 \mathrm{~cm}^{2}$ of cotton, linen, and polyester fabric and was soaked in $2 \mathrm{ml}$ methanolic extract of prodigiosin taken in different test tubes and incubated for $48 \mathrm{hr}$ at room temperature. The each fabric was completely dried and cut into five smaller pieces and was treated with acid, alkali, cold water, cold water, detergent and hot water for 20 minutes in respective test tubes. The fabric which retained the color after the washing treatment was chosen to be dyed using prodigiosin [13].

\section{RESULTS}

S. marcescens strain JAR8 was isolated from sewage water sample among five soil samples and sewage water samples. The isolate was confirmed as $S$. marcescens by its morphological, biochemical and phylogenetic characteristics. The accession number KF709428 was obtained from the NCBI Genbank data as the isolate showed 100\% similarity with $S$. marcescens strain JASM and the phylogenetic tree was constructed using neighbour joining method as depicted in Fig. 1.

The isolate was observed to be Gram-negative single rod-shaped bacilli and showed catalase positive and oxidase negative [19]. The other biochemical test such as urease, hydrogen sulphide, arabinose, and lactose fermentation showed negative whereas citrate, lysine, and the ornithine decarboxylase tests were positive for the isolate. The highest pigment production was observed in peptone glycerol broth $(1.26 \mathrm{mg} / \mathrm{ml})$ followed by nutrient broth $(0.97 \mathrm{mg} / \mathrm{ml})$ and LB broth and soybean casein digest broth showed lower production levels of prodigiosin $0.32 \mathrm{mg} / \mathrm{ml}$ and $0.21 \mathrm{mg} / \mathrm{ml}$, respectively, at $30^{\circ} \mathrm{C}$. The production of prodigiosin was found to be highest at $28^{\circ} \mathrm{C}(1.47 \mathrm{mg} / \mathrm{ml})$ temperature, but the prodigiosin content was found to be $1.28 \mathrm{mg} / \mathrm{ml}$ at

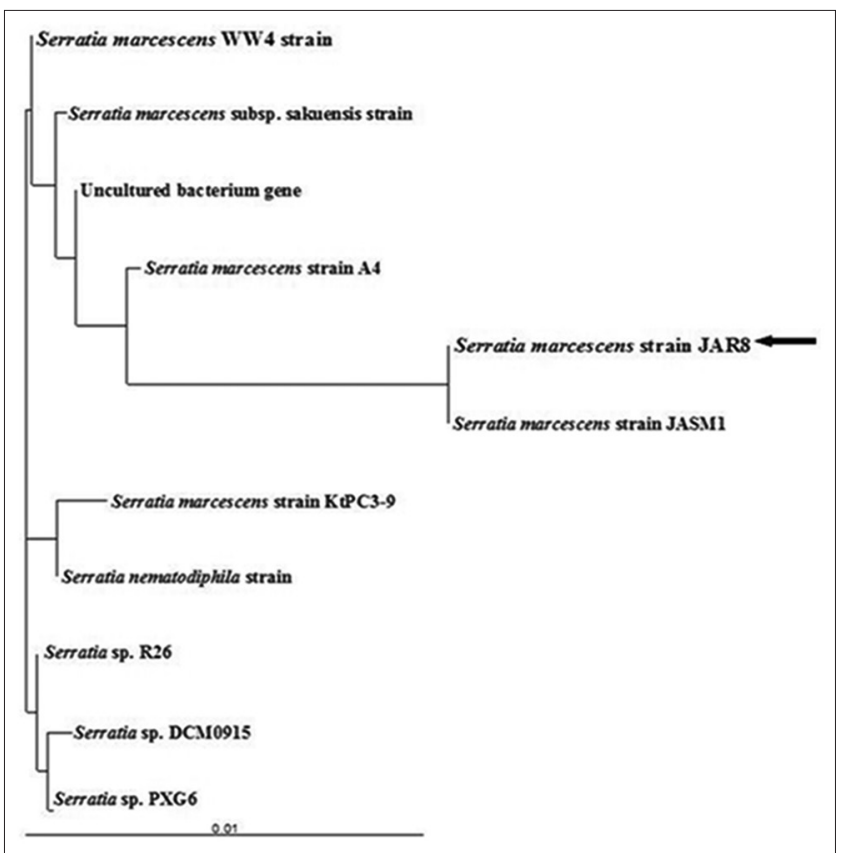

Fig. 1: Phylogenetic relationship based on 165 rRNA gene nucleotide sequences between the Serratia marcescens JAR8 and reference sequences retrieved from NCBI Gen Bank constructed through the neighbor joining method 
$30^{\circ} \mathrm{C}$ and was almostnegligible at $37^{\circ} \mathrm{C}(0.18 \mathrm{mg} / \mathrm{ml})$. The $\mathrm{pH}$ also affected the growth of pigment production and was found to reach maximum at $\mathrm{pH} 7.0$ with $1.46 \mathrm{mg} / \mathrm{ml}$ of biomass and at $\mathrm{pH} 6.0$ it was found to be $0.98 \mathrm{mg} / \mathrm{ml}$, at pH 8.0 was $1.15 \mathrm{mg} / \mathrm{ml}$ and at $\mathrm{pH} 10.0$ was $0.45 \mathrm{mg} / \mathrm{ml}$ which showed least growth with other $\mathrm{pH}$. The pigment production was carried out in fermentor for 5 day at $30^{\circ} \mathrm{C}$ and the cell mass was allowed to settle down to extract pigment. The prodigiosin pigment was effectively extracted with ethyl acetate, ethanol, and methanol using centrifugation. The separation of components of prodigiosin was analyzed by thin layer chromatography and purple, red, yellow bands were obtained with Rf of $0.54,0.86$ and 0.95 , respectively. When the methanol extract of prodigiosin was run against a mixture of methanol: ethyl acetate: chloroform in the ratio of $6: 3: 1(\mathrm{v} / \mathrm{v})$. It was observed that purple fraction was the first to be separated followed by yellow and red fractions. The yellow component was found to be unstable and was found to merge with the red component very rapidly soon after the separation. Production of prodigiosin and thin layer chromatography of strain JAR8 has been presented in Fig. 2a and b, respectively.

The prodigiosin pigment showed effective antimicrobial effect against Gram-positive bacteria than Gram-negative bacteria. The ethyl acetate, methanol, ethanol, and distilled water showed good inhibition results as shown in Tables 1 and 2 .

The highest zone of inhibition was found against $S$. aureus NCIM $5021(40.6 \pm 0.52 \mathrm{~mm})$ with methanol extract of prodigiosin pigment, whereas the weak activity was manifested against Gram-negative bacteria such as Klebsiella pneumoniae, E. coli, and P. aeruginosa. The free radical scavenging activity of the obtained pigment was analyzed by 2, 2-diphenyl-1 picrylhydrazyl, and no discoloration of purple color to yellow was observed which resulted in poor antioxidant activity which further depicts the strain JAR8 can be used specifically for active pharmaceutical antimicrobial agent. The prodigiosin pigment was evaluated for in-vitro cytotoxicity effect against human bone cancer cell line (MG 63) and was found to be effectively inhibiting cancer cells. The cytotoxicity was determined at various concentrations of prodigiosin from $12.5 \mu \mathrm{g} / \mathrm{ml}$ to $200 \mu \mathrm{g} / \mathrm{ml}$ using MTT assay. To determine cell death, prodigiosin produced by strain JAR8 $(>200 \mu \mathrm{g} / \mathrm{ml})$ is commendable to induce $50 \%$ of cell mortality, and the IC50 was calculated to be $108 \mu \mathrm{g} / \mathrm{ml}$ which exhibits dose dependent relation on cell death. Fig. 3 represents the bone cancer cell inhibition from $12.5 \mu \mathrm{g} / \mathrm{ml}$ to $200 \mu \mathrm{g} / \mathrm{ml}$.

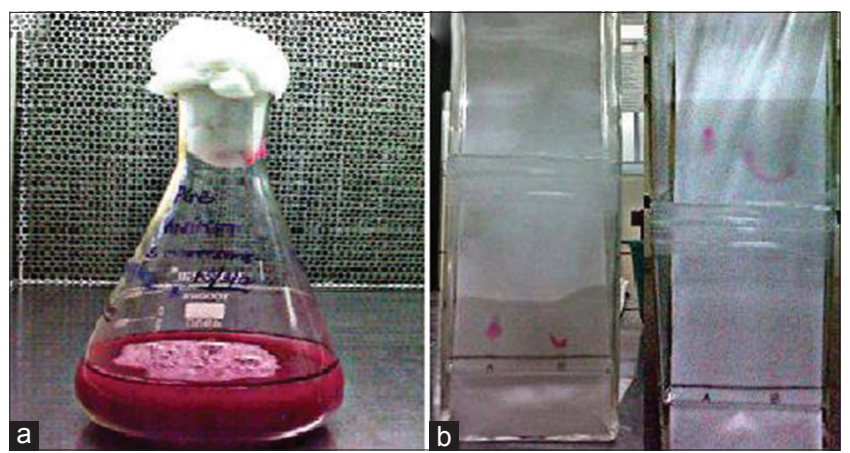

Fig. 2: (a) Production of red pigment prodigiosin by strain JAR8 in peptone glycerol broth. (b) Separation and purification of prodigiosin pigment produced by Serratia marcescens strain JAR8 using thin layer chromatography

Table 1: Antimicrobial activity of methanol and ethanol extracts of prodigiosin against clinical pathogens

\begin{tabular}{|c|c|c|c|c|c|c|c|c|}
\hline \multirow[t]{3}{*}{ Pathogens } & \multicolumn{8}{|c|}{ Zone of inhibition (mm) } \\
\hline & \multicolumn{4}{|c|}{ Methanol extract $(100 \mu \mathrm{g} / \mathrm{mL})$} & \multicolumn{4}{|c|}{ Ethanol extract $(100 \mu \mathrm{g} / \mathrm{mL})$} \\
\hline & $25 \mu \mathrm{L}$ & $50 \mu \mathrm{L}$ & $75 \mu \mathrm{L}$ & $100 \mu \mathrm{L}$ & $25 \mu \mathrm{L}$ & $50 \mu \mathrm{L}$ & $75 \mu \mathrm{L}$ & $100 \mu \mathrm{L}$ \\
\hline Staphylococcus aureus NCIM 5021 & $20.86 \pm 0.47$ & $29.03 \pm 0.35$ & $37.5 \pm 0.51$ & $40.6 \pm 0.52$ & $22.43 \pm 0.40$ & $30.6 \pm 0.59$ & $32.53 \pm 0.15$ & $35.4 \pm 0.4$ \\
\hline Escherichia coli NCIM 2645 & - & - & - & $15.3 \pm 0.51$ & - & - & - & $13.5 \pm 0.5$ \\
\hline Klebsiella pneumoniae NCIM 5029 & - & - & - & $14.46 \pm 0.41$ & - & - & - & - \\
\hline $\begin{array}{l}\text { Pseudomonas aeruginosa NCIM } \\
2957\end{array}$ & - & - & - & $15.3 \pm 0.51$ & - & - & - & $14.5 \pm 0.3$ \\
\hline Shigella sp. & - & - & $13.5 \pm 0.5$ & $15.3 \pm 0.51$ & - & $11.4 \pm 0.4$ & $12.6 \pm 0.31$ & $14.5 \pm 0.3$ \\
\hline Salmonella sp. & - & - & - & - & - & - & - & - \\
\hline Proteus mirabilis & - & - & - & - & - & - & - & - \\
\hline Alcaligenes sp. & $7.2 \pm 0.46$ & $10.6 \pm 0.40$ & $16.16 \pm 0.21$ & $19.5 \pm 0.25$ & - & - & - & - \\
\hline Klebsiella pneumoniae & - & - & - & - & - & - & - & - \\
\hline Pseudomonas aeruginosa & - & - & - & - & - & - & - & - \\
\hline Bacillus subtilis & - & - & $12.6 \pm 0.31$ & $14.5 \pm 0.3$ & - & - & - & $15.36 \pm 0.30$ \\
\hline
\end{tabular}

Table 2: Antimicrobial activity of ethyl acetate and water extracts of prodigiosin against clinical pathogens

\begin{tabular}{|c|c|c|c|c|c|c|c|c|}
\hline \multirow[t]{3}{*}{ Pathogens } & \multicolumn{8}{|c|}{ Zone of inhibition (mm) } \\
\hline & \multicolumn{4}{|c|}{ Ethyl acetate extract $(100 \mu \mathrm{g} / \mathrm{mL})$} & \multicolumn{4}{|c|}{ Prodigiosin powder+water $(100 \mu \mathrm{g} / \mathrm{mL})$} \\
\hline & $25 \mu \mathrm{L}$ & $50 \mu \mathrm{L}$ & $75 \mu \mathrm{L}$ & $100 \mu \mathrm{L}$ & $25 \mu \mathrm{L}$ & $50 \mu \mathrm{L}$ & $75 \mu \mathrm{L}$ & $100 \mu \mathrm{L}$ \\
\hline Staphylococcus aureus NCIM 5021 & $24.5 \pm 1.32$ & $30.5 \pm 0.5$ & $33.3 \pm 1.52$ & $40.3 \pm 0.57$ & $28.5 \pm 0.5$ & $32.16 \pm 0.76$ & $35.66 \pm 0.57$ & $40.3 \pm 0.57$ \\
\hline Escherichia coli NCIM 2645 & - & - & - & $18.5 \pm 0.3$ & - & - & - & - \\
\hline Klebsiella pneumoniae NCIM 5029 & - & - & - & $13.5 \pm 0.5$ & - & - & - & - \\
\hline $\begin{array}{l}\text { Pseudomonas aeruginosa NCIM } \\
2957\end{array}$ & - & - & - & $14.0 \pm 0.4$ & - & - & - & - \\
\hline Shigella sp. & - & - & - & - & $10.6 \pm 0.40$ & $10.6 \pm 0.40$ & $13.5 \pm 0.5$ & $14.0 \pm 0.4$ \\
\hline Salmonella sp. & - & - & - & - & $16.16 \pm 0.28$ & $16.16 \pm 0.28$ & $19.43 \pm 0.45$ & $21.26 \pm 0.46$ \\
\hline Proteus mirabilis & - & - & - & - & - & - & - & - \\
\hline Alcaligenes sp. & - & - & - & - & $10.33 \pm 0.57$ & $14.0 \pm 0.4$ & $18.5 \pm 0.50$ & $19.43 \pm 0.45$ \\
\hline Klebsiella pneumoniae & - & - & - & - & - & - & - & - \\
\hline Pseudomonas aeruginosa & - & - & - & - & - & - & - & - \\
\hline Bacillus subtilis & - & - & $11.43 \pm 0.37$ & $13.13 \pm 0.61$ & $9.13 \pm 0.61$ & $12.36 \pm 0.32$ & $13.73 \pm 0.60$ & $14.0 \pm 0.40$ \\
\hline
\end{tabular}


The dyeing of different fabric with prodigiosin pigment was found to be effective. The different fabrics (cotton, linen, and polyester) were subjected to the treatment with acid, alkali, cold water, hot water, cold water, and detergent for 20 minutes. The color of the dye for cotton and linen fabrics was completely retained in cases of acid and cold water treatments, whereas a small amount of discoloration resulted when treated with alkali and hot water and detergent as shown in Fig. 4a and b. Polyester textile did not retain the color after washing with different solutions. Thus, the pigment can be used to dye cotton and linen fabrics to get textiles as major industrial application.

\section{DISCUSSION}

In this study, $S$. marcescens JAR8 produces natural and effective pharmaceutically important secondary metabolite identified as prodigiosin. It is bacterial secondary metabolite which serves as antimicrobial, anticancer, and immunosuppressant agent. The optimization of culture medium components, $\mathrm{pH}$ and temperature parameters improve the system of bacteria resulting in high yield of metabolite [20]. The maximum production of prodigiosin was yielded in
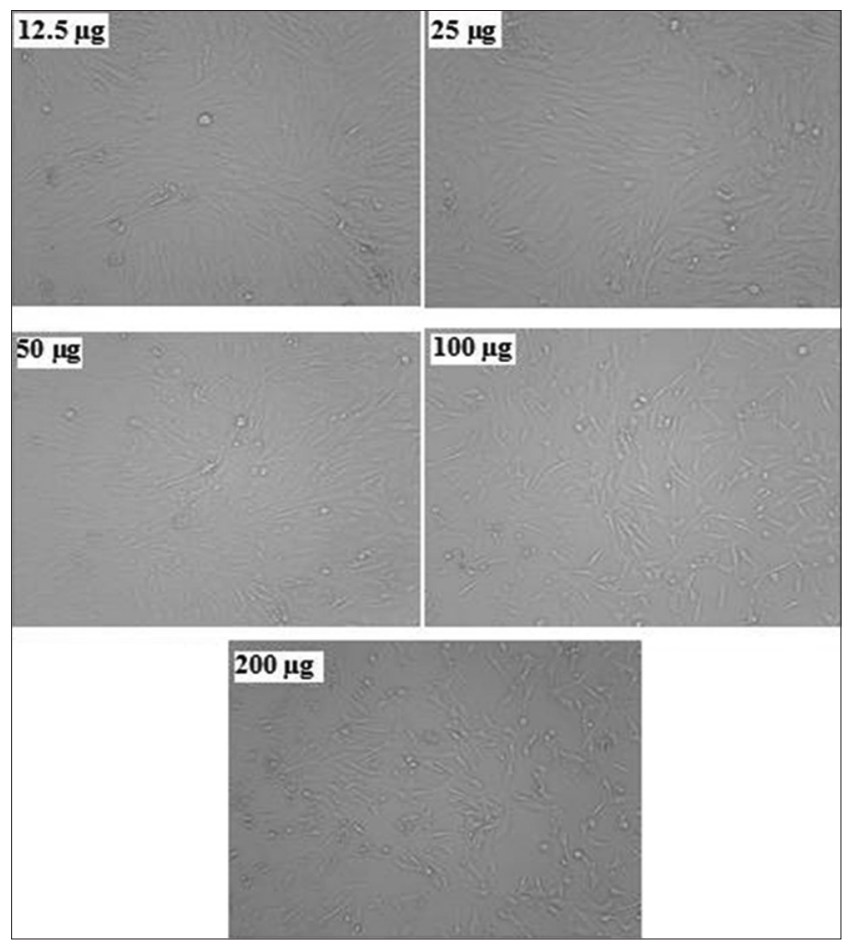

Fig. 3: Effect on prodigiosin obtained from strain JAR8 on bone cancer cells with various concentrations
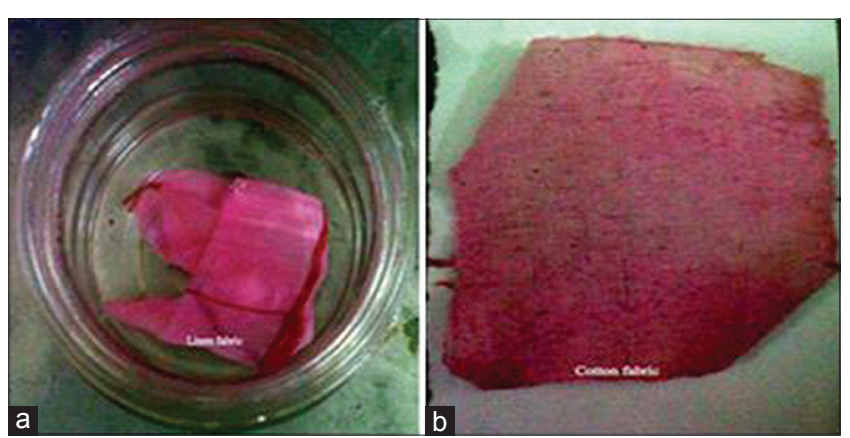

Fig. 4: (a) Linen fabric piece with retention of prodigiosin pigment from Serratia marcescens strain JAR8 after acid, alkali, detergent, cold, and hot water treatment. (b) Cotton fabric piece with retention of prodigiosin pigment from S. marcescens JAR8 after acid, alkali, detergent, cold, and hot water treatment peptone glycerol broth which was similarly observed in Gulani et al. [13] findings report the combination of peptone and glycerol to increase the production of prodigiosin. The parameters such as $\mathrm{pH}$ and temperature also play a significant role affecting the pigment production. Our results were in agreement with Giri el al. [21] as maximum production of pigment was obtained at lower temperature on peptone-glycerol medium. Prodigiosin obtained from $S$. marcescens JAR8 is a natural bacterial pigment and also possesses effective antimicrobial, anticancer properties whereas there are many medicinal plant pigments which have been successfully employed in pharmaceutical industries. To sustain plant species, $S$. marcescens JAR8 can be extensively used for the production of prodiogosin to meet pharmaceutical and dyeing industries needs.

\section{CONCLUSION}

The present investigation reveals that prodigiosin produced by S. marcescens JAR8 isolated from sewage water samples collected around the VIT University, Vellore, possess clinical and industrial applications. This study deals with the successful optimization of the cultural parameters that facilitated the enhanced production and extraction of the prodigiosin produced by $S$. marcescens JAR8 strain. The antimicrobial and dyeing potential of the obtained pigment from JAR8 strain could be aimed at the possible future usage of prodigiosin as a therapeutic agent against infectious diseases. The pigment obtained is economically effective and can be categorized as microbial natural product for further pharmaceutical applications.

\section{ACKNOWLEDGMENTS}

The authors wish to acknowledge National Collection of Industrial Microorganisms (NCIM), Pune, India, for providing various clinical isolates for the present work.

\section{REFERENCES}

1. Cho YJ, Park JP, Hwang HJ, Kim SW, Choi JW, Yun JW. Production of red pigment by submerged culture of Paecilomyces sinclairii. Lett Appl Microbiol 2002;35(3): 195-202

2. Parekh S, Vinci VA, Strobel RJ. Improvement of microbial strains and fermentation processes. Appl Microbiol Biotechnol 2000;54(3):287-301

3. Durán N, Teixeira MF, De Conti R, Esposito E. Ecological-friendly pigments from fungi. Crit Rev Food Sci Nutr 2002;42(1):53-66.

4. Grimont F, Grimont PA. The genus Serratia. In: The Prokaryotes. New York: Springer; 2006. p. 219-244.

5. Kobayashi N, Ichikawa Y. Separation of the prodigiosin-localizing crude vesicles which retain the activity of protease and nuclease in Serratia marcescens. Microbiol Immunol 1991;35(8):607-14.

6. Matsuyama T, Murakami T, Fujita M, Fujita S, Yano I. Extracellular vesicle formation and biosurfactant production by Serratia marcescens. Microbiology 1986;132(4):865-75.

7. Alihosseini F, Ju KS, Lango J, Hammock BD, Sun G. Antibacterial colorants: Characterization of prodiginines and their applications on textile materials. Biotechnol Progr 2008;24(3):742-7.

8. Songia S, Mortellaro A, Taverna S, Fornasiero C, Scheiber EA, Erba E, et al. Characterization of the new immunosuppressive drug undecylprodigiosin in human lymphocytes: Retinoblastoma protein, cyclin-dependent kinase-2, and cyclin-dependent kinase-4 as molecular targets. J Immunol 1997;158(8):3987-95.

9. Someya N, Nakajima M, Watanabe K, Hibi T, Akutsu K. Influence of bacteria isolated from rice plants and rhizospheres on antibiotic production by the antagonistic bacterium Serratia marcescens strain B2. J Gen Plant Pathol 2003;69(5):342-7.

10. Su WT, Tsou TY, Liu HL. Response surface optimization of microbial prodigiosin production from Serratia marcescens. J Taiwan Inst Chem Eng 2011;42(2):217-22.

11. Liu WY, Zeng J, Wang L, Dou YT, Yang SS. Halobacillus dabanensis $\mathrm{sp}$. Nov. And Halobacillus aidingensis sp. Nov. Isolated from salt lakes in Xinjiang, China. Int J Syst Evol Microbiol 2005;55(5):1991-6.

12. Sharma G, Dang S, Gupta S, Gabrani R. Identification and molecular characterization of bacteria having antimicrobial and anti-biofilm activity. Int J Pharm Pharm Sci 2016;8(10):111-4

13. Gulani C, Bhattacharya S, Das A. Assessment of process parameters influencing the enhanced production of prodigiosin from Serratia 
marcescens and evaluation of its antimicrobial, antioxidant and dyeing potentials. Malays J Microbiol 2012;8(2):116-22.

14. Lynch DL, Worthy TE, Kresheck GC. Chromatographic separation of the pigment fractions from a Serratia marcescens strain. Appl Microbiol 1968;16(1):13-20.

15. Chatterjee A, Nishanthini D, Sandhiya N, Abraham J. Biosynthesis of titanium dioxide nanoparticles using Vigna radiata. Asian J Pharm Clin Res 2016;9(4):1-4

16. Mosmann T. Rapid colorimetric assay for cellular growth and survival: Application to proliferation and cytotoxicity assays. J Immunol Methods 1983;65(1-2):55-63.

17. Monks A, Scudiero D, Skehan P, Shoemaker R, Paull K, Vistica D, et al. Feasibility of a high-flux anticancer drug screen using a diverse panel of cultured human tumor cell lines. J Natl Cancer Inst 1991;83(11):757-66.
18. Chatterjee A, Archana L, Niroshinee V, Jayanthi A. Biosynthesis of lanthanum nanoparticles using green gram seeds and their effect on microorganisms. Res J Pharm Biol Chem Sci 2016;7(2):1462-70.

19. Khanam B, Chandra R. Isolation and identification of endophytic bacteria producing bright red pigment from the dye yielding plant Beta vulgaris L. Int J Pharm Pharm Sci 2015;7(5):220-4.

20. Giri AV, Anandkumar N, Muthukumaran G, Pennathur G. A novel medium for the enhanced cell growth and production of prodigiosin from Serratia marcescens isolated from soil. BMC Microbiol 2004;4:11

21. Elkenawy NM, Yassin AS, Elhifnawy HN, Amin MA. Optimization of prodigiosin production by Serratia marcescens using crude glycerol and enhancing production using gamma radiation. Biotechnol Rep (Amst) 2017;14:47-53 